\title{
Dermatological pathology in an African prison environment: Guinean experience
}

Thierno Mamadou Tounkara ${ }^{1,2^{*}}$, Mohamed Macire Soumah ${ }^{1,2}$, Moussa Keita ${ }^{1,2}$, Fode Bangaly Sako ${ }^{1,3}$, Fode Amara Traore ${ }^{1,3}$, Talhatou Diallo ${ }^{2}$, Issiagha Camara ${ }^{4}$, Djibril Sylla ${ }^{1,5}$, Boh Fanta Diane ${ }^{1,2}$, Adama Dicko ${ }^{6,7}$, Balde Houleymatou ${ }^{1,2}$ and Mohamed Cisse ${ }^{1,2}$

*Correspondence: tounkm@yahoo.fr

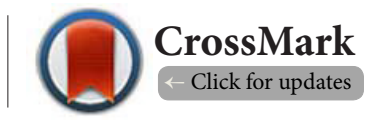

${ }^{1}$ University Gamal Abdel Nasser of Conakry, France.

${ }^{2}$ Department of Dermatology-STD, Donka National Hospital, Conakry University Hospital, France.

${ }^{3}$ Department of Infectious and Tropical Diseases, Donka National Hospital, Conakry University Hospital, France.

${ }^{4}$ Infirmary of the Central House, France.

${ }^{5}$ Department of Internal Medicine, Donka National Hospital, Conakry University Hospital, France.

${ }^{6}$ Department of Dermatology, Bamako, Mali, France.

${ }^{7}$ CNAM ex Marchoux Institute, Bamako, Mali, France.

\begin{abstract}
Introduction: The aim of this study was therefore to provide a detailed description of the dermatological conditions presented by prisoners and to determine their determining factors in the largest detention center in Guinea.

Material and methods: This work took place in the central house of Conakry. It is a penitentiary establishment built at the beginning of the 20th century for a theoretical capacity of three hundred people. Its occupancy rate in 2013 was $377 \%$, reflecting saturation. From April 1 to 17, 2013, we conducted a descriptive and analytical cross-sectional study that included all prisoners with one or more dermatosis and who agreed to participate in the study. For each inmate, the different types of dermatosis were identified. The frequency of the shower, the use of soap for the shower, the change of clothes and the sanitation of the cells were analyzed by the Chi2 of Pearson at the threshold of $5 \%$. The study was authorized by the prison authorities.
\end{abstract}

Results: One thousand one hundred and thirty-one detainees were examined; 320 had dermatosis, a prevalence of $27.3 \%$. They were 292 men and 28 women with an average age of 30 years and extremes of 15 and 70 years. Infectious dermatosis were the most represented, with 247 cases $(77.2 \%)$ with a predominance of scabies in 146 inmates, and dermatophytis in 58 inmates. Non-infectious dermatosis accounted for $22.8 \%$ of dermatosis with a predominance of contact eczema noted in 27 patients. One hundred and eighty-nine $(59 \%)$ patients showered irregularly, $62 \%$ did not use soap for the shower, $51 \%$ irregularly changed their clothes after showering, $70 \%$ of the cells were irregularly cleaned. Seventy-five percent of patients had never had a dermatological consultation. We found a statistically significant relationship between the occurrence of infectious dermatosis and hygienic conditions in prison settings including the frequency of the shower, the use of soap and the frequency of changing clothes.

Conclusion: The profile of skin disease observed in the Guinean prison environment is no different from that of the majority of resource-limited countries. These are pathology that can be the subject of preventive measures and/or can be aggravated by precarious conditions of hygiene and detention.

Keywords: Infectious dermatosis, prison, defectivehygiene, Guinea

\section{Introduction}

The prison population is a disadvantaged and vulnerable population, the majority of whom are youth and adults. Over population and poor sanitary conditions in the prison environment offer favorable conditions for the development of various pathologies, including dermatological pathologies. 
Tounkara et al. Dermatology Aspects 2017,

http://www.hoajonline.com/journals/pdf/2053-5309-5-1.pdf

doi: 10.7243/2053-5309-5-1

These have been the subject of several studies [1-5], with frequencies varying according to the context: $7.7 \%$ in Belgian prisons [6] 27\% in prisons in Switzerland [7], 56.2\% in Cameroon [2] 49.2\% in Nigeria [4]. They are responsible for significant morbidity.

Nowadays, no data centered on dermatological pathology in prisons are available in Guinea.

The purpose of this study was therefore to provide a detailed description of the dermatological pathology presented by inmates in the largest detention center in Guinea and to determine the determining factors.

\section{Methods}

Site of study

This work took place in the central house of Conakry. It is a penitentiary establishment built at the beginning of the 20th century for a theoretical capacity of three hundred (300) people. Its occupancy rate in 2013 was $377 \%$ and reflects saturation.

\section{Type and length of study}

From 01 to 17 April 2013, we carried out a cross-sectional, descriptive and analytical study that included all prisoners with one or more dermatologic pathology and freely agreed to participate in the study.

The consultations were carried out by two dermatologist physicians assisted by the Physician of the establishment and a nurse. The diagnosis was based exclusively on anamnestic and clinical arguments.

The data were: age, sex, education, marital status, length of incarceration, number of inmates per cell, history of consultation, frequency of shower, use of Soap for the shower, changing clothes, sanitizing cells and different types of dermatoses.

The frequency of the shower, the use of soap for the shower, the change of clothes and the sanitation of the cells were analyzed by the Pearson chi-square at the $5 \%$ threshold or by Fisher's exact test.

Ethically, the study was conducted after the free and voluntary consent of the detainees. Moreover, it was carried out after the agreement of the prison authorities.

\section{Results}

During the reporting period, one thousand one hundred and thirty-one patients were examined. Of these, 320 had dermatosis, a prevalence of $27.3 \%$.

These were 292 men and 28 women with an average age of 30 years and the extremes of 15 and 70 years. The majority of patients (42.5\%) were in the 20-29 age group years. They were out of school in $40.6 \%$ of the patients, had a pre-university level of $52.2 \%$ and a university level of $7.2 \%$ of the patients. The socio-demographic characteristics are detailed in Table 1. Seventyfive percent of patients had never had a dermatological consultation. Infectious dermatosis were the most common, with 247 cases $(77.2 \%)$ with a predominance of scabies (Figure 1) in 146 inmates (59.1\%), dermatomycosis (Figure 2) in 58 patients.
Table 1. Socio-demographic Characteristics of study population.

\begin{tabular}{llll}
\hline Variable & & Number & Percentage (\%) \\
\hline Age (years) & $<20$ & 43 & 13.4 \\
& $20-29$ & 136 & 42.5 \\
& $30-39$ & 87 & 27.2 \\
& $40-49$ & 35 & 10.9 \\
& $50-59$ & 14 & 4.4 \\
& $\geq 60$ & 5 & 1.6 \\
\hline Sex & Male & 292 & 91.7 \\
& Female & 28 & 8.3 \\
\hline Level of education & Unschooled & 130 & 40.6 \\
& Pre-university & 167 & 52.2 \\
& Superior & 23 & 7.2 \\
\hline Marital status & Singles & 212 & 66.3 \\
& Married & 98 & 30.7 \\
& Divorced & 4 & 1.2 \\
& Widowed & 6 & 1.9 \\
\hline Duration of & $<1$ & 244 & 76.2 \\
incarceration (year) & $1-5$ & 72 & 22.5 \\
& $>5$ & 4 & 1.3 \\
\hline
\end{tabular}

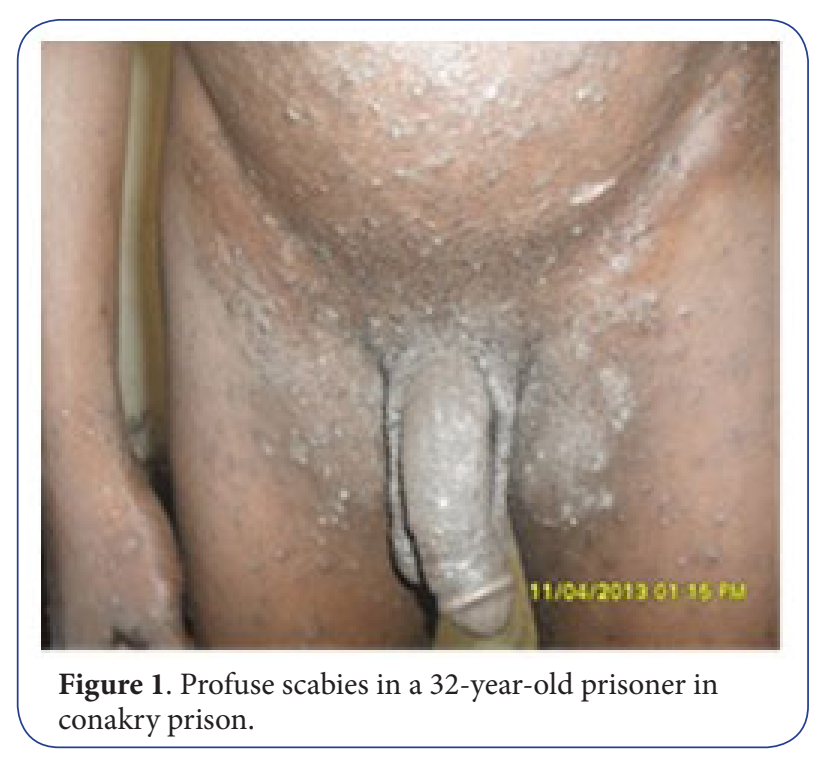

Non-infectious dermatosis accounted for $22.8 \%$ of dermatosis with a predominance of contact eczema noted in 27 patients. The clinical characteristics of the patients are summarized in Table 2.

One hundred and ninety-nine (59.1\%) patients were showering irregularly, one hundred and ninety-nine patients (62.2\%) did not use soap for showering, one hundred and sixty-four patients (51.3\%) Irregularly changed clothes after showering, $70 \%$ of the cells were irregularly cleaned. We found a statistically significant relationship between the occurrence of infectious dermatosis and the hygiene conditions in prisons, including the frequency of showering, the use of soap and the frequency of change of clothing (Table 3 ).

\section{Discussion}

This study was the first to document the epidemiological and 


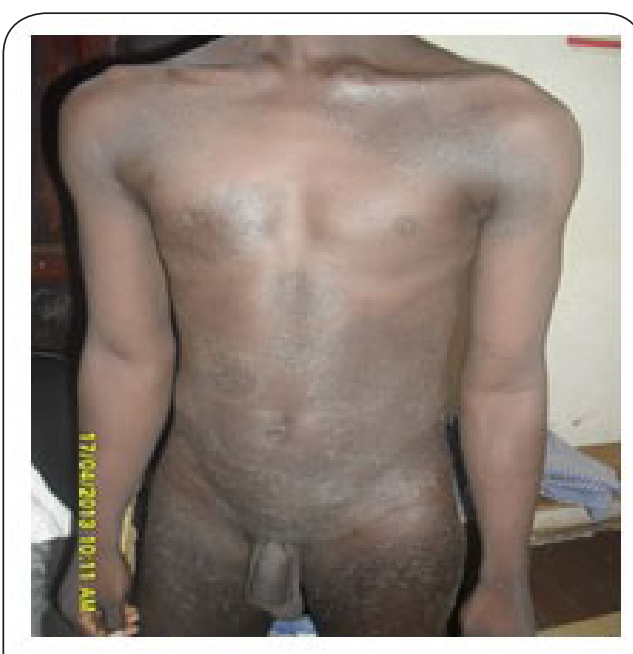

Figure 2. Profuse dermatomycosis in a 28-year-old man in conakry prison.

Table 2. Clinical characteristics of the patients.

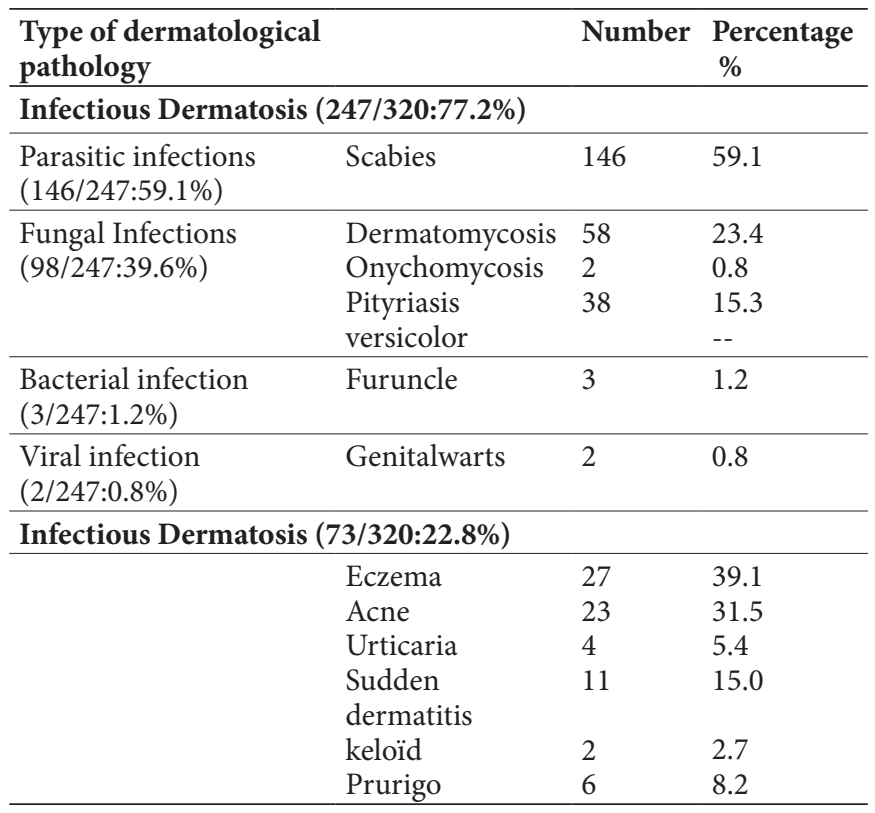

Table 3. Distribution of the prisoners according to the occurrence of skin disease according to the risk factors.

\begin{tabular}{lllll}
\hline Factors & \multicolumn{2}{l}{$\begin{array}{l}\text { Infectious } \\
\text { Dermatosis } \\
\text { Yes }\end{array}$} & $\begin{array}{l}\text { Exact Fisher } \\
\text { Test }\end{array}$ & P-value \\
\hline Frequency of shower & & & \\
\hline Regular & 99 & 32 & Positive & $\mathrm{p}<0.05$ \\
Irregular & 176 & 13 & -- & -- \\
\hline Using soap for shower & & & \\
\hline yes & 90 & 31 & Positive & $\mathrm{p}<0.05$ \\
No & 185 & 14 & -- & -- \\
\hline Change of clothes after shower & & \\
\hline Regular & 58 & 26 & Positive & $\mathrm{p}<0.05$ \\
Irregular & 217 & 19 & -- & -- \\
\hline
\end{tabular}

clinical profile of dermatosis in Guinean prison settings.

The main findings indicate a situation similar to that reported by other authors, namely a high prevalence of infectious diseases and youth in the prison population $[2,5,8]$.

It reports a prevalence of $28.3 \%$. This result is consistent with data from the literature, which highlights the frequency of dermatosis in prisons and accounts for the extent of dermatological conditions in Guinean prison settings.

They were dominated by infections noted in $77.2 \%$ of patients. Our result is superior to that of Parajuli et al., [3] in Nepal, who report a $34.8 \%$ prevalence of infectious dermatosis but similar to that reported by Kouotou et al., [2] in Cameroon who reported a prevalence of $76.4 \%$ infectious dermatosis.

Prison over crowding, promiscuity and poor hygienic conditions are all factors that favor this strong representativeness of the scabies and dermatomycosis observed during our study.

The over population observed in our study is also reported by several other authors [4,8-10].

These infectious pathologies are transmissible and require early management and special hygiene measures to limit their spread. The detainees were mostly young, with an average age of 30 years, and extremes of 15 and 71 years. This result is not only a reflection of the youth of the prison population but also calls for the need to promote integration approaches so that young people can play their role better as a development actor. The result is in line with those of Kouotou et al in Cameroon [2] and B. Khatibi et al., [11] in France, which report averages of 32 years and 34 years respectively. The sex ratio was in favor of men at 10.42. This is the image of recruitment because there was a male predominance in prison. Inmates were single in $66.3 \%$ of the cases and $40.6 \%$ were out of school. B. DEMOURES et al., [12] reported almost exclusively male prisoners aged between 13 and 67 (48\% aged 20-30 years) single in $59 \%$ of the cases and $55 \%$ of whom were enrolled in school.

Regarding hygiene conditions, only $5.9 \%$ of the cells were sanitized daily, $59.1 \%$ of the prisoners took irregularly, the shower, $62.2 \%$ showered without soap and only $26.3 \%$ wore clean clothes after the shower. We found a statistically significant relationship between prison hygiene conditions (including frequency of shower, use of shower soap, frequency of change of clothes) and the occurrence of infectious dermatosis with $\mathrm{P}<0.05$. Oninla OA et al., [8] and Makoutode $\mathrm{M}$ et al., [9] in their respective studies, the existence of a statistically significant link between the hygiene conditions of the prison environment and the occurrence of infectious dermatosis was established.

In our study, we identified 247 cases of infectious dermatosis, a frequency of $77.2 \%$ and 73 cases of noninfectious dermatosis, or a frequency of $22.8 \%$. Our data are similar to those of Oninla OA et al., [8] in Nigeria, which found $63.6 \%$ infectious dermatosis, $36.4 \%$ non-infectious dermatosis. Among infectious dermatosis, $59.1 \%$ (146/247) of mange, 39.6\% (98/247) of mycotic dermatosis dominated by dermatomycosis were found in 58 patients, i.e., $23.4 \%$ followed by pityriasis versicolor in 38 Patients, is $15.3 \%$. In our study, as in those of several other 
Tounkara et al. Dermatology Aspects 2017,

http://www.hoajonline.com/journals/pdf/2053-5309-5-1.pdf

doi: 10.7243/2053-5309-5-1

authors, mycotic conditions also remain of high prevalence in prison settings $[\mathbf{8}, \mathbf{1 3}, \mathbf{1 4}]$. In the study by $\mathrm{B}$. Khatibi et al in France, the low rate of scabies was due to the anti-scabious treatment and to the isolation during one week of the prisoners for whom this diagnosis was evoked during the systematic medical consultation that follows their Transfer from their place of custody [12].

The high prevalence of infectious diseases also reported by Kuruvila et al [15] could be reduced by improving hygiene conditions.

Non-infectious pathologies were dominated by contact dermatitis.

The discomfort caused by the various pathology encountered did not seem to be a priority, as only 82 of them (25.6\%) said that they had previously consulted the prison infirmary for these dermatosis and $83 \%$ benefited from treatment. This result would probably be related to the benign character of the different pathology observed.

This work, which was based on a single penitentiary institution, can not be extrapolated to the whole country, but given the socio-economic conditions, we hypothesize that the profile described here would be comparable to that of the other centers detention throughout the country.

A wider study including prisons in the regions may confirm or disprove our hypothesis.

\section{Conclusion}

The profile of skin disorders observed in the Guinean prison environment is no different from that of the majority of resource-limited countries. These are pathologies that can be the subject of preventive measures and/or can be aggravated by precarious conditions of hygiene and detention.

Despite the apparent benignity of the pathologies encountered, it would be important to develop regular monitoring of the health status of prisoners and to establish appropriate management to reduce morbidity.

\section{Competing interests}

The authors declare that they have no competing interests.

\section{Authors' contributions}

\begin{tabular}{|l|c|c|c|c|c|c|c|c|c|c|c|c|}
\hline Authors' contributions & TMT & MMS & MK & FBS & FAT & TD & IC & DS & BFD & AD & BH & MC \\
\hline Research concept and design & $\checkmark$ & $\checkmark$ & $\checkmark$ & -- & -- & $\checkmark$ & -- & -- & -- & -- & -- & $\checkmark$ \\
\hline Collection and/or assembly of data & $\checkmark$ & $\checkmark$ & $\checkmark$ & -- & -- & $\checkmark$ & $\checkmark$ & -- & -- & -- & -- & -- \\
\hline Data analysis and interpretation & $\checkmark$ & $\checkmark$ & $\checkmark$ & $\checkmark$ & $\checkmark$ & -- & $\checkmark$ & -- & -- & -- & $\checkmark$ & -- \\
\hline Writing the article & $\checkmark$ & $\checkmark$ & $\checkmark$ & -- & -- & $\checkmark$ & -- & -- & -- & -- & -- & -- \\
\hline Critical revision of the article & $\checkmark$ & $\checkmark$ & $\checkmark$ & $\checkmark$ & $\checkmark$ & $\checkmark$ & -- & $\checkmark$ & $\checkmark$ & $\checkmark$ & $\checkmark$ & $\checkmark$ \\
\hline Final approval of article & $\checkmark$ & $\checkmark$ & $\checkmark$ & $\checkmark$ & $\checkmark$ & $\checkmark$ & $\checkmark$ & $\checkmark$ & $\checkmark$ & $\checkmark$ & $\checkmark$ & $\checkmark$ \\
\hline
\end{tabular}

\section{Acknowledgements}

We would like to thank the prison authorities and the authorities of the Faculty of Medicine of Conakry for their support in making this work possible.

\section{Publication history}

Editor: Alireza Heidari, California South University (CSU), USA. Received: 06-Apr-2017 Final Revised: 05-May-2017

Accepted: 10-May-2017 Published: 21-May-2017

\section{References}

1. Roodsari R, Malekzad F and Ardakani ME. Skin diseases in male prisoners. Indian J Dermatol Venereol Leprol. 2007; 73:55-6. | Article | PubMed

2. Kouotou E A, Adegbidi H, Nansseu J R N, Bogne LM, Sieleunou I and Tatsa JT et al .Epidemiological and clinical profiles of skin diseases in subsaharan african prisons: a crosssectional study from the West Region of Cameroon. Clinical Dermatology. 2016; 4:46-51. | Article

3. Parajuli N, Jonkman-Veenstra G and Jonkman M. Skin Diseases In A Nepali Prison. Journal of Chitwan Medical College. 2014; 4.

4. Oninla OA, Onayemi O, Olasode OA and Oninla SO. Pattern of dermatoses among inmates of Ilesha Prison, Nigeria. Niger Postgrad Med J. 2013; 20:174-80. | Article | PubMed

5. Akakpo AS, Ekouevi DK, Toure AM, Saka B, Sogan A, d’Almeida S, Kombate $K$, Tchangai-Walla $K$ and Pitche $P$. [Skin disease and HIV infection among inmates in Lome, Togo: a study of 194 prisoners]. Med Sante Trop. 2014; 24:326-8. | Article | PubMed
6. Feron JM, Paulus D, Tonglet R, Lorant V and Pestiaux D. Substantial use of primary health care by prisoners: epidemiological description and possible explanations. J Epidemiol Community Health. 2005; 59:651-5. I Article | PubMed Abstract | PubMed FullText

7. Wolff H, Sebo P, Haller DM, Eytan A, Niveau G, Bertrand D, Getaz L and Cerutti $B$. Health problems among detainees in Switzerland: a study using the ICPC-2 classification. BMC Public Health. 2011; 11:245. | Article | PubMed Abstract | PubMed FullText

8. Oninla OA and Onayemi O. Skin infections and infestations in prison inmates. Int J Dermatol. 2012; 51:178-81. I Article I PubMed

9. Makoutode M, Dogmo S, Ouendo E-M, Agossou Th, Bessaoud K. Frequency of pathologies and health risk in the civilian prison of Cotonou in Benin. Médecine d'Afrique noire. 2004; 51:105-11.

10. Ribeiro Fde A, Taciro E, Guerra MR and Eckley CA. Oral ivermectin for the treatment and prophylaxis of scabies in prison. J Dermatolog Treat. 2005; 16:138-41. | Article | PubMed

11. Khatibi B, Bambe A, Chantalat C, Resche-Rigon M, Sanna A, Fac C, Bagot $M$ and Guibal F. [Teledermatology in a prison setting: $A$ retrospective study of 500 expert opinions]. Ann Dermatol Venereol. 2016; 143:41822. | Article | PubMed

12. Demoures B, Emmanuel Nk and Leonard M. Primary health care in prisons: about a Cameroonian experience. Cahier Santé.1998 ; 8:212-6.

13. Zida A, Barro-Traore F, Dera M, Bazie Z, Niamba P and Guiguemde TR. [Epidemiological and etiological aspects of superficial fungal infections among prison inmates in Ouagadougou, Burkina Faso]. J Mycol Med. 2015; 25:e73-9. | Article | PubMed

14. Bayle P, Cuzin L, Paul C, Blanc A, Grill S, Rouge D and Telmon N. Prisoners 
Tounkara et al. Dermatology Aspects 2017,

http://www.hoajonline.com/journals/pdf/2053-5309-5-1.pdf

and skin diseases in Toulouse, France: epidemiological analysis and evaluation of life impact. J Eur Acad Dermatol Venereol. 2009; 23:52-7. I Article | PubMed

15. Kuruvila M, Shaikh MI and Kumar P. Pattern of dermatoses among inmates of district prison--Mangalore. Indian J Dermatol Venereol Leprol. 2002; 68:16-8. | Article | PubMed

\section{Citation:}

Tounkara TM, Soumah MM, Keita M, Sako FB, Traore FA, Diallo T, Camara I, Sylla D, Diane BF, Dicko A, Houleymatou B and Cisse M. Dermatological pathology in an African prison environment: Guinean experience. Dermatol Aspects. 2017; 5:1.

http://dx.doi.org/10.7243/2053-5309-5-1 